\title{
Tool dilemmas of innovation
}

\author{
Jolanta Sala \\ Powiślański College, ul. \\ 11Listopada 13, 82-500 Kwidzyn, \\ Poland \\ Email: jolasala@interia.pl
}

\author{
Halina Tańska \\ University of Warmia and Mazury \\ in Olsztyn, ul. Słoneczna 54, \\ 10-689 Olsztyn, Poland \\ Email: tanska@uwm.edu.pl
}

\begin{abstract}
The article has indicated the phenomenon of the low-level of ICT use in Polish enterprises as well as its consequences, in particular an unimpressive activity of innovative companies. The approach that has been proposed is to identify the multidimensional expanse of information management through the identification and analysis of information gaps. The article has exposed the importance of the seven vulnerable areas such as development, competency, motivation, emotion, generation, efficiency, technique and technology. Tools, individualized for each company in relation to the information and ICT, are an important determinant of innovation.
\end{abstract}

\section{INTRODUCTION}

CT technologies depreciate a number of traditional skills, among other things they have eliminated the core competences of engineering-technical workers which used to be crucial (that is, the use of slide rule, drawing board, rapidograph). The phenomenon of the depreciation is in particular visible in the Polish industry as its negative effect was multiplied by improper realization of the system transformation. In Polish service companies the situation is not good as well. Jeffrey Sampler, a famous researcher of ICT technologies suggests, that the companies should make a list of competences they are currently lacking (incompetence, lack of skills, awkwardness) and which they will need in the future, instead of determining their key competences. This was the intention of the article's authors who present different information gaps referring to few areas, although they do not use all types identified both in professional literature and practice.

It is worth considering "what far-reaching effects are connected to the so-called digital disability syndrome, which can be understood as depriving some communities of the access to information and their sources (the Internet) or their inability to acquire it" [1].

The authors have been publishing articles on improper approach towards creating the base for informative society in our country [2], [3] as its effects are visible now. Poland is at the end of the ranking consisting of the EU countries. One

This work was not supported by any organization can analyze in detail the reasons for this situation, but it is difficult to expect pointing out consequences with respect to the institutions and personal responsibility for the disappointing results. Therefore, it is more pragmatic to focus on the key aspects of repairing the current situation. Undoubtedly, one of the effects is the low percentage of innovatively active and innovative enterprises in Poland $(18,1 \%$ of industrial enterprises and $13,5 \%$ of the ones providing services) [4], and one of the reasons are the mistakes in conducting the policy connected to ICT technologies.

\section{CONCEALMENT OR THE LACK OF AWARENESS}

The authors have repeatedly indicated that in various studies, reports, and analysis on the use of ICT in socioeconomic life their authors move on the border between the official image and the truth. This phenomenon is quite common and it occurs also in governmental institutions, the Central Statistical Office and others [5]. Summing up, reporting on the complacency as well as the optimism go much too far and the measurements are interpreted too loosely and imprecisely. This applies also to the enterprises and individuals (households).

The proper use of ICT in the economy has a direct impact on the competitiveness and innovativeness of Polish enterprises. Unfortunately, the use of ICT in enterprises has often an image character and this has an influence on reporting. Therefore, it is difficult to discern why it is so bad while it so good? There is no doubt the cause of this condition is an "easy" investment in modern "furnishings" of the offices in PCs and the lack of elementary skills of using them by the employees. The lack of training or improper selection of courses deepen the bad situation in the case of more experienced employees (usually those aged $30+$, which did not experienced the mass ICT education from the level of primary school). In the conditions of unemployment the process of hiring young people is limited, and among this group the best ones decided to emigrate for financial reasons.

Therefore, it is difficult to give a verdict in this particular case, whether there is a concealment of or even distorted 
reporting or it is a genuine lack of awareness of the average low-level use of ICT (many times on the level of IT illiteracy). In such cases it is also difficult to speak about the usage of ICT to increase the innovative activeness of the enterprise.

Unfortunately, inadequate ICT tools and the lack of skills to use them both in private and professional lives often result in the unconscious and unvested ability to obtain information from various sources available in a digital form. This phenomenon is acute in the Polish SME sector. While analyzing information issues in the economy it is essential to appeal to the achievements of a new scientific discipline which is certainly the economics of information specified by professor J.Oleński. In this paper, it is worth recalling the importance of the meta-informational minimum and metainformational and information gaps.

\section{META-INFORMATIONAL AND INFORMATIONAL MINIMUM}

The thesis which does not need to be verified is that social groups and economic subjects can perform their duties when the informational needs in this regard are established. Much more far-reaching is the belief that the deepening social, cultural and economic polarization of the communities, regions and countries is "a consequence of the ever-growing functional minimum of information, high-level and sustained growth of the informational requirements" [6]. It should be assumed that the reason for this popularization is the difference in the available information resources and opportunities to access the global informational systems. A situation in which there are disparities cited here leads to the creation of "information gap". It is universal and considered from many angles. According to the authors, it covers many areas (planes), thus it seems legitimate to discuss its dimensions.

The attempt of dimensional analysis should be started from the meta-level and from recalling the definition of meta-information (that is information about information) that can be entered into a perfect circular shape (Fig. 1) which allows avoiding the justification of the order and adding or removing individual dimensions (such as paradigm, infrastructure, human, economic subject, environment) depicted in Figure 1 in a form of a pie slice. The similar situation concerns identifying the gaps (that is the development, technology-technological, competence, educational, language, politic-legal and quality ones etc.), which were localized in direct environment of "information dimensions circle".

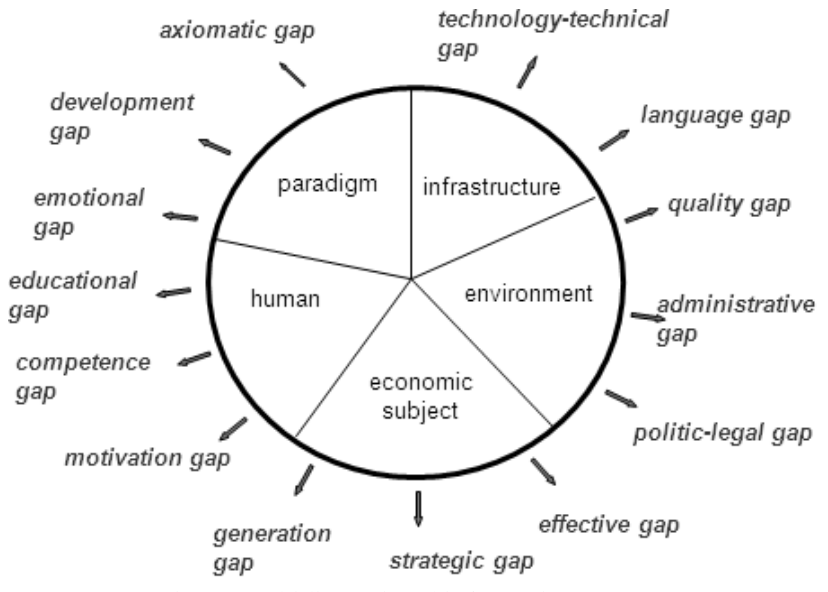

Fig. 1 Multidimensional information expanse

Undoubtedly, the graphic model of multidimensional information expanse presented in Figure 1 requires a deeper interpretation. It illustrates the complexity of the analyzed phenomena and inspires to define a more uniform and useful structure. A distinct perspective presented in Figure 2 meets these requirements.

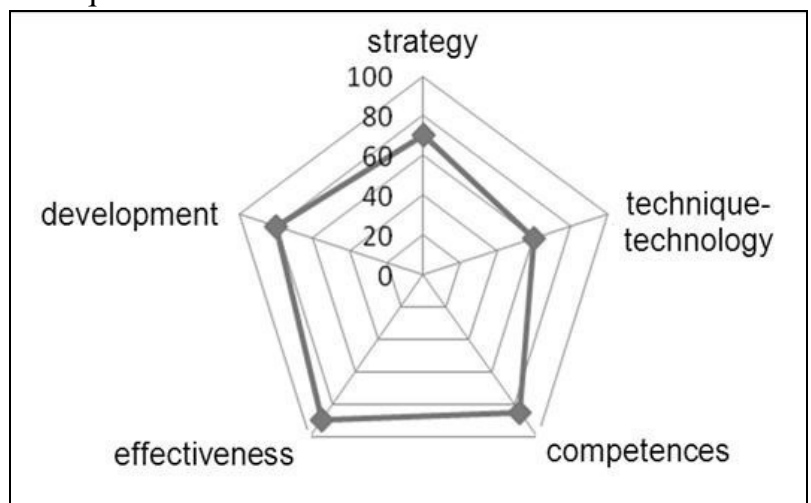

Fig. 2 Dimensions of meta-informational gap

The positioning of meta-informational gap on a radar chart enables significantly more precise analysis of the socioeconomic reality and, above all, measuring the quality of events. Today one can notice a steady technical, organizational and civilization progress which results in enlarging the gap between available resources of information and information which is necessary for efficient, effective operation in specific situations. In highly developed countries the governments and socio-economic organizations do not allow the creation of such a situation because one of the important tasks of the national information infrastructure is to fill the information gap. This means the elimination of discrepancies between information that is available and information that is needed. A simplified model of information gap is presented on Figure 3, where the coordinates are the amount of information and the complexity of the problem. There is a close correlation (elation) between the size of the gap (reducing vulnerability) and incurred costs (expenses incurred). Not always it is worth aiming at minimizing the information gap due to the economic aspect. 


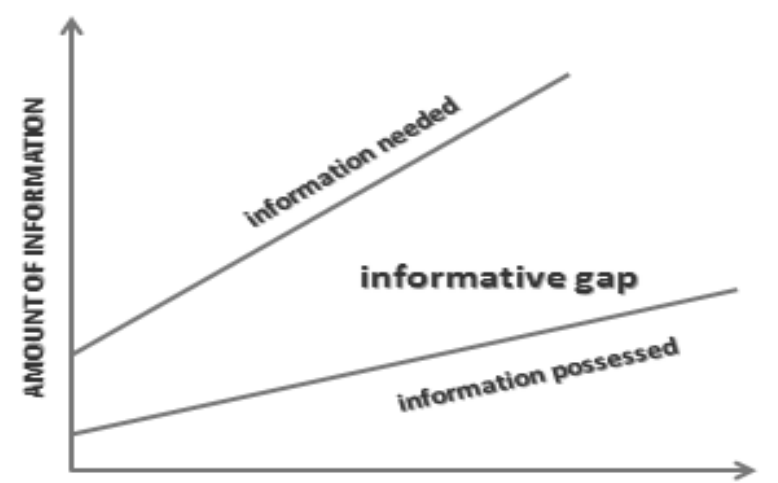

COMPLEXITY OF THE PROBLEM

Fig. 3 Information gap

Precise determining information gap planes is associated with the definition of multidimensional expanse of information management (EIM). To concrete EIM one can assume the record in the form of Cartesian quotient according to the formula (1):

$\mathrm{EIM}=\mathrm{X}(\mathrm{Z}, \mathrm{P}, \mathrm{TI}, \mathrm{F}, \mathrm{t})$,

where:

EIM - information expanse management,

$\mathrm{X}$ - the sign of Cartesian quotient on elements presented in brackets,

$\mathrm{Z}$ - information resources,

$\mathrm{P}$ - information processes,

TI - information technologies,

$\mathrm{F}$ - functions of managing (planning, organizing, control etc.),

$\mathrm{t}$ - time horizon of the management (operative, tactical, strategic).

In such a way it is easy to create ,the map of tasks and problems" where ,each point on information expanse management is a specified task related to a specific resource in a particular time horizon, in the context of specified function of management" [7].

Therefore, one can return to the consideration of the informational needs using two complementary approaches cited in the academic textbook quoted above. The first proposed by prof. H. Egeman considers informational needs in the context of the scope (resources, processes and information technologies), time horizon of the management (operative, tactical and strategic management) as well as the function of managing information (planning, organizing, control etc). It is understandable that it involves "planning, organization, implementation and control of the implementation of the ongoing work in using informational organizations (including access to information) and current (daily) administration of information to ensure proper quality, consistency and safety (including confidential) information" [7]. According to the second approach whole information needed for the user $\mathrm{U}$ in his daily business or because of his or her non-economic interests conditions the type of problem to be solved Q as well as the knowledge and experience of an individual (user U). Prof. B. Stefanowicz divided informational needs into two complementary subsets. Iu symbol represents a subset of the information needed to solve $\mathrm{Q}$, and already available to the user. And the symbol of $\mathrm{L}$, is a subset of this information, which is needed and is not directly accessible (Fig. 4). The development of informational needs can be written down by using the formula (2):

$$
<U_{s} Q_{x} M>\Rightarrow I \Rightarrow I u \cup L
$$

The most important features of the set L, which was called an information gap by B. Stefanowicz can be characterized in the following way:

1) The gap is always "somebody's" gap so it cannot be analyzed in separation to a specified user and the problem to be solved;

2) Volatility in time t;

3) Fuzziness of the set L borders L;

4) The set of needed but unknown information divided on the basis of content, mutually connected by multiple relationships.

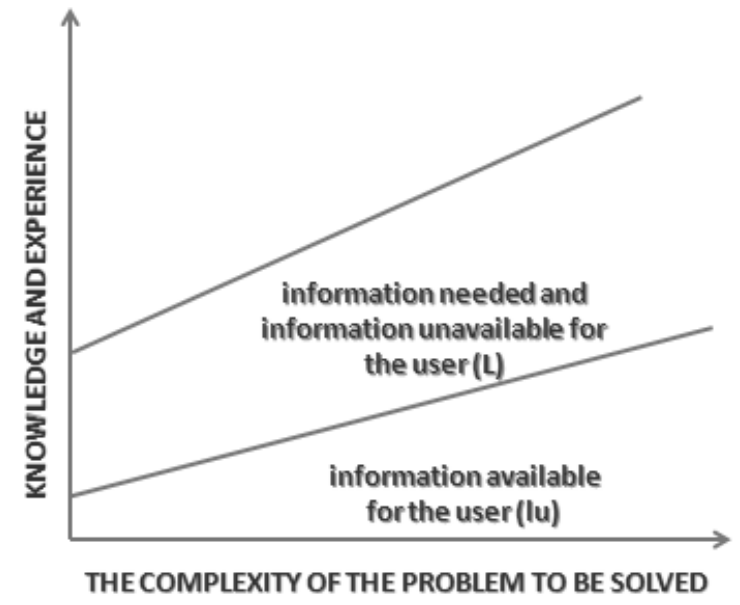

Fig. 4 Information gap - knowledge and experiences view

\section{PRECISE ANALYSIS OF GAPS AS THE KEY TO PERFECTNESS}

The abundant literature in the field of information society and economic practice research conducted by the authors confirmed the need for a new approach [8], which will not only facilitate the survival of businesses, but will allow them to become more innovative and pro-developmental. In this regard, the term development gap should be mentioned. It means the difference between the potential actions (for example organizational culture, management skills, logistics skills, available resources, that is, passive force) and the potential effects (for example efficiency and cultural aspirations, the structure of power, features strategic leadership). In other words, it is a difference between the desired and real state of the enterprise. So the development gap is the difference between production abilities of the enterprise and actual achievements. In many cases the creation of development gap is connected to the lack of ability of the management staff to guarantee and maintain a 
proper pace of enterprise's development as well as the lack of proper tools.

The pace of development of enterprises is highly dependent on the employees and their competences as well as bilateral (creative) relationship between the employee and the employer. For companies operating in area of a constant change it is reasonable to question whether the employees have sufficient competences to perform the work tasks according to new requirements. Their failure means the arrival of the competence gap and the need to diagnose the areas. Competence gap in the organization is a collection of knowledge, skills and attitudes which the company hasn't obtained yet and which are a precondition for the proper functioning of the organization after the implementation of the changes. Triangle of competence with basic dependencies is presented in Figure 5.

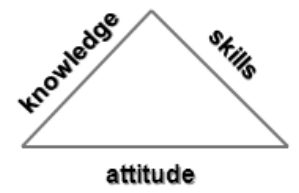

Fig. 5 The competence triangle - the relationship between the factors

Although fig. 5 is more suggestive, in practice its usage is limited. Nevertheless, there are techniques and instruments supporting the ones willing to control the competence gap. However, one must accept the standards of competences created in a form of European and national competence frameworks (ERK, PRK) and also keep up with changes enforced by the fast development of ICT.

At the same time one should develop and deepen the proactive and pro-innovative involvement of most employees otherwise the phenomenon of motivation gap (MG) will appear, which according to the concept of D.A. Nadler and E. F. Lawler is the difference between the two values, that is the level of employees' expectations about a particular stimulus (A) and degree of meeting these expectations by an incentive system (B). Formula (3) presents motivational gap in a more formal way:

$$
\mathrm{MG}=\mathrm{B}-\mathrm{A} \text {. (3) }
$$

Fig. 6 presents the motivational gap in a very unequivocal way.



Fig. 6 Motivational gap as the difference between the expected and actual behavior of the employee [9]

It is also worth looking at the company as a diverse set of individuals (employees) teaming two worlds within its borders: the people who live in an active way and people who work for a few hours to live. Recently passion and entrepreneurial attitudes are promoted as a desirable behavior. They break down and turn around the traditional image of the division of work invested in the life of man and reverse the proportions. The change in the area is clearly presented below (Fig. 7). Life begins to be consumed by the work/activity. In professional literature, this phenomenon is identified as emotional gap [9].

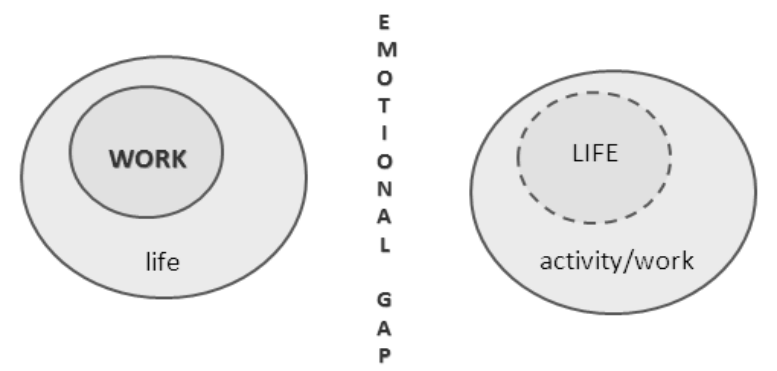

Fig. 7 Two sides of supposedly the same world [10]

It should also be noted that only a devoted employee is aware of the needs of the business and working with others, with the aim of increasing productivity for the sake of the economic subject. At the same time in the last decades of the twentieth century and two decades of the twenty-first century in the workplace a new generation of so called "virtual reality generation" and "green generation" appeared, which is a major challenge for the managers. In the professional literature, "the difference in the set of values i.e. shared by different age groups is often called generation gap" [11].

In the context of team management the gap in efficiency seems particularly interesting. Stoner and Wankel perceive it as a determinant of quality. They note that it is "the difference between the tasks set out in the formulation of objectives and results, which is likely to be reached in the case of the continuation of the current strategy. Efficiency gap may be the result of determining more difficult tasks or result from the designation of insufficient effectiveness in the past due to the effective prevention of competition, changes in the environment or loss of resources, or because of the failure to rethink the strategy. The higher the efficiency gap is, the greater should be the change in strategy" [12].

Unfortunately, due to exponential growth of information, the processes of globalization and competition, the issue of information management becomes complex and requires appropriate tools, techniques and technologies. It is difficult not to agree with the authors Grudzewski and Hajduk, who define the technical and technological gap as relatively permanent difference of the technology potential in the various national economies, determined by measuring the difference in the levels of the creation of products and their production. The change of situation in which technical and technological gap is eliminated will require additional resources for $\mathrm{B}+\mathrm{R}$ and reorientation of the existing approach toward the economy to a modern approach. 


\section{CONCLUSION}

Issues related to the information gap constitute a multifaceted and complex research problem, which can be analyzed from different perspectives. Multidimensionality of the concept of an information gap and the meta-informational gap raises difficulties both in its explicit definition and interpretation as well as in the process of measuring. Understanding the information gap helps in determining the actions involving its restriction, and such actions are necessary even in the context of macroeconomic.

Identification of information gap is definitely a dynamic process. While comparing fourteen gaps defined in multidimensional information expanse on Figure 1, the existence of only seven gaps was signalized, that is development, competence, motivational, emotional, generation, effective and technical-technological ones. In economic practice exposing their utility requires, in the case of all economic subjects, an individual precision. It may even turn out that other dimensions will be needed. Only after considering necessary modifications one can gather the ICT tools, competences and methodology of development keeping in mind the philosophical aspect The concept of development with the element of evaluation is superior in relation to the idea of development.

The authors have collaborated in formulating such an approach toward design and production for businesses from Pomerania. The effectiveness of this approach is not yet tested and focuses on the tools of integrated computer systems such as $\mathrm{CAD} / \mathrm{CAM} / \mathrm{CAE}$ for employees working on engineering and technical positions.

\section{REFERENCES}

[1] W. M. Grudzewski, I. K. Hejduk, Zarządzanie technologiami. Zaawansowane technologie i wyzwanie ich komercjalizacji. Difin, Warszawa, 2008, p.29.

[2] J. Sala, H. Tańska, „Kwalifikacje społeczeństwa informacyjnego”,. In: Problemy społeczeństwa informacyjnego, A. Szewczyk, ed. vol I, Uniwersytet Szczeciński Wydział Nauk Ekonomicznych I Zarządzania Instytut Informatyki w Zarządzaniu, Wydawnictwo Printshop, Szczecin, 2007, p.108-115.

[3] J. Sala, H. Tańska, „Wykluczenia w globalnym społeczeństwie informacyjnym $\mathrm{w}$ kontekście niedorozwoju rynku usług telekomunikacyjnych i pocztowych", in: Funkcjonowanie rynku telekomunikacyjnego i pocztowego w warunkach postępującej elektronizacji gospodarki, H. Babis, ed., Uniwersytet Szczeciński Wydział Zarządzania i Ekonomiki Usług Katedra Ekonomiki I Organizacji Telekomunikacji Katedra Polityki Gospodarczej Łączności, Zeszyty naukowe, Wydawnictwo Naukowe Uniwersytetu Szczecińskiego, Szczecin, 2007.

[4] Innovative activity of enterprises in 2008 - 2010. 2011. CSO (GUS) SO in Szczecin, Warszawa, p.149.

[5] J. Sala, H. Tańska, „Rozwiązania instytucjonalne na rzecz transferu wiedzy i kompetencji”, in Zeszyty Naukowe Politechniki Łódzkiej, vol. 53, Łódź, 2013.

[6] J. Oleński, Elementy ekonomiki informacji. Katedra informatyki Gospodarczej I Analiz Ekonomicznych, Wydział Nauk Ekonomicznych, Uniwersytet Warszawski, Warszawa, 2000, pp.497498.

[7] A. Rokicka-Broniatowska, Wstęp do informatyki gospodarczej. (red.), Szkoła Główna Handlowa, Warszawa, 2006, p.148.

[8] J. Sala, H. Tańska, „Kształcenie kadr dla potrzeb gospodarki elektronicznej”, in: Współczesne aspekty informacji, Monografie I Opracowania, vol. 551, ,J. Goliński, K. Krauze, ed., Szkoła Główna Handlowa w Warszawie, Warszawa, 2008, pp.299-307.

[9] R. .Rutka, M. Czerska, Metoda identyfikacji zdolności systemu motywacyjnego do kreowania zachowań oczekiwanych przez pracodawcę, in Zeszyty Naukowe Politechniki Łódzkiej, vol. 51, Łódź, 2013, p.77.

[10] J. Strużyzna, „Puzle „bycia zatrudnionym” - wyzwania nowego HRM dla menedżerów”, in Zeszyty Naukowe Politechniki Łódzkiej, vol. 51, Łódź, 2013, p. 43.

[11] J. A. F. Stoner, Ch. Wankel, Kierowanie. PWE, Warszawa, 2011, p. 447 .

[12] J. A. F. Stoner, Ch. Wankel, Kierowanie. PWE, Warszawa, 1992, p. 112 . 